\title{
A ferrous oxalate mediated photo-Fenton system: Toward an increased biodegradability of indigo dyed wastewaters
}

\author{
Michel Vedrenne ${ }^{a, b}$, Ruben Vasquez-Medrano ${ }^{a, *}$, Dorian Prato-Garcia ${ }^{a}$, Bernardo A. Frontana-Uribe ${ }^{c, 1}$, \\ Margarita Hernandez-Esparza ${ }^{a}$, Juan Manuel de Andrés ${ }^{b}$

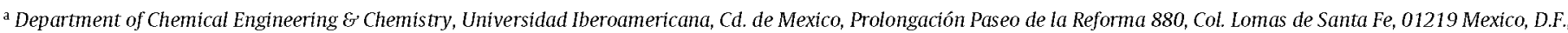 \\ Mexico \\ ${ }^{\mathrm{b}}$ Department of Chemical E' Environmental Engineering, Technical University of Madrid (UPM), José Gutiérrez Abascal 2, 28004 Madrid, Spain \\ ${ }^{c}$ Centro Conjunto de Investigaciôn en Química Sustentable UAEM-UNAM, Km. 14.5, Carretera Toluca-Atlacomulco, 50200 Toluca, Estado de México, Mexico
}

\section{H I G H L I G H T S}

- Indigo wastewaters are successfully treated with a solar assisted oxidation reaction.

- Using ferrous oxalate complexes, the efficiency of the treatment increases.

- Increasing peroxide concentrations did not improve the treatment substantially.

- The best removals of TOC and COD were reached with the smallest peroxide dose.

- A final complete biodegradability was obtained for these wastewaters.

\section{A R T I C L E I N F O}

Keywords:

Advanced oxidation process

Ferrous oxalate complex

Indigo dye

Photo-Fenton

Biodegradability

\begin{abstract}
A B S T R A C T
This study assessed the applicability of a ferrous oxalate mediated photo-Fenton pretreatment for indigodyed wastewaters as to produce a biodegradable enough effluent, likely of being derived to conventional biological processes. The photochemical treatment was performed with ferrous oxalate and hydrogen peroxide in a Compound Parabolic Concentrator $(C P C)$ under batch operation conditions. The reaction was studied at natural $\mathrm{pH}$ conditions (5-6) with indigo concentrations in the range of $6.67-33.33 \mathrm{mg} \mathrm{L}^{-1}$, using a fixed oxalate-to-iron mass ratio $\left(\mathrm{C}_{2} \mathrm{O}_{4}{ }^{2-} / \mathrm{Fe}^{2+}=35\right)$ and assessing the system's biodegradability at low (257 $\left.\mathrm{mg} \mathrm{L}^{-1}\right)$ and high $\left(1280 \mathrm{mg} \mathrm{L}^{-1}\right) \mathrm{H}_{2} \mathrm{O}_{2}$ concentrations. In order to seek the optimal conditions for the treatment of indigo dyed wastewaters, an experimental design consisting in a statistical surface response approach was carried out. This analysis revealed that the best removal efficiencies for Total Organic Carbon (TOC) were obtained for low peroxide doses. In general it was observed that after $20 \mathrm{~kJ} \mathrm{~L}^{-1}$ almost every treated effluent increased its biodegradability from a $\mathrm{BOD}_{5} / \mathrm{COD}$ value of 0.4 . This increase in the biodegradability was confirmed by the presence of short chain carboxylic acids as intermediate products and by the mineralization of organic nitrogen into nitrate. Finally, an overall decrease in the $\mathrm{LC}_{50}$ for Artemia salina indicated a successful detoxification of the effluent.
\end{abstract}

\section{Introduction}

Dyes can be satisfactorily removed from textile wastewaters by the means of biological, chemical and physico-chemical processes [1-4]. The combination of anaerobic-aerobic processes is considered a low cost alternative to deal with colored wastewa-

\footnotetext{
* Corresponding author at: Department of Chemical Engineering \& Chemistry, Universidad Iberoamericana, Mexico City, Mexico, Prolongación Paseo de la Reforma 880, Col. Lomas de Santa Fe, 01219 Mexico City, Mexico. Tel.: +52 5559504074 ; fax: +525559504279 .

E-mail address: ruben.vasquez@uia.mx (R. Vasquez-Medrano).

1 Permanent position at Instituto de Química UNAM.
}

ters. According to $[3,4]$, dyes are decolorized in the anaerobic phase while its by-products, mainly aromatic amines, are mineralized in the aerobic phase. However, the combination of anaerobic-aerobic processes reveals some operative limitations during the degradation of colored compounds. Recently, it has been evidenced that factors such as the Hydraulic Retention Time (HRT), wastewater loading rate, primary substrate type and concentration, dye concentration and dye structure, affect both decolorization and aromatic amine removal [1-5]. Furthermore, the release of aromatic moieties is considered an important issue because they are considered as highly recalcitrant, toxic, carcinogenic and mutagenic substances to several species [6,7].

Physical and chemical methods like adsorption [2,8,9], membrane filtration $[2,10,11]$, and coagulation-flocculation [10,12-14] 
have been applied to decolorize indigo dyes due to its efficiency and simplicity. Nevertheless, these methods have some operational problems like sludge generation, membrane fouling, phase change of the pollutants and high operative cost [2]. On the other hand, Advanced Oxidation Processes (AOPs) are considered a suitable way to decolorize textile wastewaters $[15,16]$. These processes involve the generation of $\mathrm{HO}^{*}$ radicals which are considered the most powerful oxidizing agents in aqueous phase $\left(E^{0}: 2.8 \mathrm{~V} / \mathrm{SHE}\right.$, Standard Hydrogen Electrode). An interesting technology to produce $\mathrm{HO}$ • radicals is via the Fenton reagent, which is initiated by the proper combination of iron salts and peroxide (Eq. (1)).

$\mathrm{Fe}^{2+}+\mathrm{H}_{2} \mathrm{O}_{2} \rightarrow \mathrm{Fe}^{3+}+\mathrm{HO}^{*}+\mathrm{OH}^{-}$

In the absence of photons, the accumulation of $\mathrm{Fe}^{3+}$ and its complexation with carboxylate species appears to be the principal drawback for Fenton processes due to the reduction of the degradation rates [17]. Nonetheless, solar radiation can induce the photo-reduction (Eq. (2)) and photo-decarboxylation of $\mathrm{Fe}^{3+}$ species (Eq. (3)) allowing catalyst regeneration and producing additional radicals [15-17].

$\mathrm{Fe}(\mathrm{OH})^{2+}+h v \rightarrow \mathrm{Fe}^{2+}+\mathrm{HO}^{\bullet}$

$\mathrm{Fe}(\mathrm{OOCR})^{2+}+h v \rightarrow \mathrm{Fe}^{2+}+\mathrm{CO}_{2}+\mathrm{R}^{\bullet}$

The Fenton and photo-Fenton processes are performed efficiently at acidic conditions ( $\mathrm{pH} 2.8-3.0$ ) which is considered an important drawback to deal with textile effluents $(\mathrm{pH} \mathrm{6-10).} \mathrm{Therefore,} \mathrm{the}$ degradation of dyes through Fenton processes can include at least four stages: (1) $\mathrm{pH}$ adjustment, (2) oxidation, (3) neutralization and (4) coagulation-precipitation, the last one especially related with the generation of $\mathrm{Fe}(\mathrm{OH})_{3(\mathrm{~s})}$. The coagulation stage may result problematic basically because contaminants may undergo phase change.

Furthermore, the presence of colored compounds might reduce light penetration which may have considerable influence on the reaction rate due to the reduction of photons available for the photocatalytic reduction of the catalysts as indicated in Eq. (2) $[15,17]$. It is important to note that reaction (2) exhibits a relatively low quantum yield $\Phi \mathrm{Fe}^{2+}=0.14 \pm 0.04$ at $313 \mathrm{~nm}$ [17]. On the other hand, the quantum yield of $\mathrm{Fe}^{2+}$ photoproduction can be enhanced by the photolysis of the highly photosensitive ferrous oxalate and ferrioxalate complexes $[15,18,19]$. Likewise, organic ligands-mediated oxidation systems are faster and more efficient than the simple Fenton systems [18]. Kwan and Chu [19] demonstrated that the use of ferrous oxalate is the best option compared with other organic ligands such as citrate or EDTA. The presence of the ferrous-oxalate complex speeds up the production of hydroxyl radicals according to reaction (4) $[18,19]$. Additionally, oxalate can combine with dissolved oxygen to form superoxide radicals $\left(\mathrm{O}_{2}{ }^{--}\right)$ that are likely to produce $\mathrm{H}_{2} \mathrm{O}_{2}$ according to Eqs. (5) and (6), respectively $[18,19]$.

$$
\begin{aligned}
& \mathrm{Fe}^{\mathrm{II}}\left(\mathrm{C}_{2} \mathrm{O}_{4}\right)^{2-}+\mathrm{H}_{2} \mathrm{O}_{2} \rightarrow \mathrm{Fe}^{\mathrm{III}}\left(\mathrm{C}_{2} \mathrm{O}_{4}\right)^{2-}+\mathrm{HO}^{\bullet}+\mathrm{OH}^{-} \\
& \mathrm{C}_{2} \mathrm{O}_{4}{ }^{--}+\mathrm{O}_{2} \rightarrow 2 \mathrm{CO}_{2}+\mathrm{O}_{2}{ }^{\bullet-} \\
& \frac{\mathrm{O}_{2}{ }^{\bullet}}{\mathrm{HO}_{2}}+\mathrm{H}^{+} \rightarrow \mathrm{H}_{2} \mathrm{O}_{2}+\mathrm{O}_{2}
\end{aligned}
$$

Although AOPs appear to be an important alternative to degrade colored compounds, operative costs have limited its feasibility at industrial scale [2]. However, it is possible to take advantage of a combination of AOPs and biological processes for the development of robust and economic alternatives to remove biorecalcitrant compounds $[2,20,21]$. In a combined AOP-biological process, the oxidative stage is frequently aimed to improve its biodegradability. Then, by means of an aerobic post-treatment stage an economic degradation of the residual organic carbon might be feasible [21].
In these systems, it is important to assure the complete removal of the recalcitrant compound and/or the transformation of the original compound in highly biodegradable by-products. Therefore, the robustness of the combined process is highly dependent of the preliminary step [22].

Mexico is the world's largest denim producer, manufacturing around 270 million meters of denim per year. It is important to note that around $15 \%$ of the indigo used is lost during the dyeing process as well as due to its low solubility indigo dye is mainly adsorbed onto activated sludge. Therefore, the aim of this work is to evaluate the performance of ferrous oxalate type complexes to enhance the biodegradability of indigo-polluted wastewater at near neutral conditions ( $\mathrm{pH} 5-6$ ). These analyses will be carried out on simulated wastewaters, prepared according to modern dyetechniques. Firstly, the pre-treatment performance at near neutral conditions in order to reduce the impact of the conditioning stages was evaluated. Then, the feasibility to operate in a combined photoassisted-aerobic strategy to mineralize indigo dyes in conventional wastewater plants was tested. Future and novel research lines to be developed will involve the use of real indigo-dyed wastewater.

\section{Materials and methods}

\subsection{Sample preparation}

The simulated wastewaters were prepared using a synthetic indigo dye (C.I.: 73,000, $\mathrm{C}_{16} \mathrm{H}_{10} \mathrm{~N}_{2} \mathrm{O}_{2}$, M.W.: $262 \mathrm{~g} \mathrm{~mol}^{-1}$, dye content: $95 \%$ ) at three arbitrary concentrations: 20,50 and $100 \mathrm{mg} \mathrm{L}^{-1}$. The initial indigo concentration was chosen based upon typical values used in denim dyeing and manufacturing processes [23]. The raw synthetic dye was mixed with water and then hydrolyzed into its soluble leuco-indigo form; to accomplish this, firstly the $\mathrm{pH}$ was adjusted to 12 with $\mathrm{NaOH}$ (J.T. Baker, ACS: $96 \%$ ), heated up to $50^{\circ} \mathrm{C}$, and then reduced with sodium dithionite $\left(\mathrm{Na}_{2} \mathrm{~S}_{2} \mathrm{O}_{4}\right.$, Sigma-Aldrich, ACS: 90\%) [24]. The solution was left to cool to room temperature and then its $\mathrm{pH}$ was adjusted to 6 using concentrated sulfuric acid (Sigma-Aldrich, ACS: 96\%). The conditioning process to the initial problem solutions resulted in final indigo concentrations of 6.67 , 16.67 , and $33.33 \mathrm{mg} \mathrm{L}^{-1}$.

\subsection{Sample pre-conditioning}

The $\mathrm{pH}$ measurements were performed with a Thermo Orion 4 Star potentiometer. The reagents $\mathrm{FeCl}_{2} \cdot 4 \mathrm{H}_{2} \mathrm{O}$ (ACS: 98\%) and $\mathrm{Na}_{2} \mathrm{C}_{2} \mathrm{O}_{4}$ (ACS: 99.5\%) were provided by Químicos Monterrey (Monterrey, Mexico) and used as received. The ferrous oxalate solution was prepared daily by mixing $10 \mathrm{~mL}$ of ferrous chloride solution ( $20 \mathrm{mg} \mathrm{L}^{-1}$ ), $10 \mathrm{~mL}$ of sodium oxalate solution ( $300 \mathrm{mg} \mathrm{L}^{-1}$ ) and stored in darkness. The hydrogen peroxide solution ( $30 \%$ volume/volume) was provided by J.T. Baker. The theoretical $\mathrm{H}_{2} \mathrm{O}_{2}$ concentration required for the degradation of indigo was calculated through the Chemical Oxygen Demand (COD), as shown in Eq. (7) [25]. The actual $\mathrm{H}_{2} \mathrm{O}_{2}$ concentrations implemented in this work were adjusted to typical values for the treatment of textile wastewaters through the photo-Fenton reaction [17].

$\left[\mathrm{H}_{2} \mathrm{O}_{2}\right]=\frac{34}{16}\left(\mathrm{COD}_{\text {indigo }}\right)$

where applicable, the excess $\mathrm{H}_{2} \mathrm{O}_{2}$ from the samples was extinguished with a sodium thiosulfate $\left(\mathrm{Na}_{2} \mathrm{~S}_{2} \mathrm{O}_{3}\right.$, Sigma-Aldrich, ACS: 93\%) solution $\left(4 \mathrm{~g} \mathrm{~L}^{-1}\right)$.

\subsection{Experimental setup}

The tests were performed in 10 Pyrex glass tubes of $50 \mathrm{~mL}$ each (transmittance: $\lambda=290 \mathrm{~nm}$ ). These were mounted on an own-built 
a

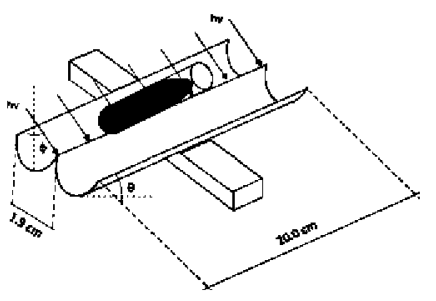

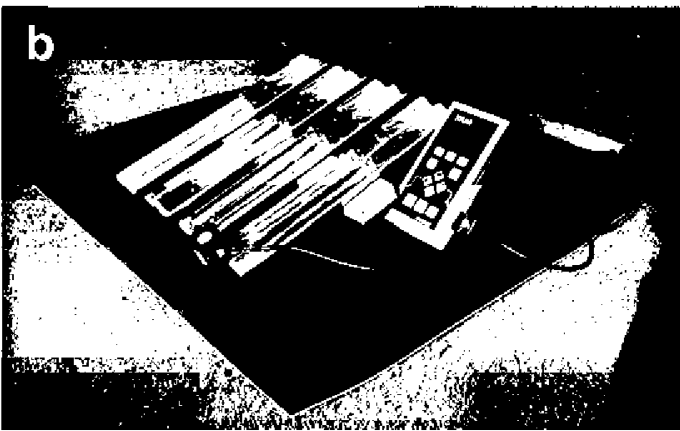

Fig. 1. (a) Schematic representation of the experimental set-up. (b) Fully mounted CPC treatment device.
Compound Parabolic Concentrator (CPC) with 16 slots, constructed using the design ratios indicated by [26,27] (Fig. 1). The CPC was placed $20^{\circ}$ above the horizontal, in a shadow-free, westward oriented yard of the F Building at the Universidad Iberoamericana, in Mexico City. All the experiments were carried out from 9:00 a.m. to 2:00 p.m., initiating the experimentation on January 7th, 2011 and ending it on April 16th, 2011. The total accumulated radiation received by the tubes was measured using a calibrated Solar ${ }^{(B)}$ Light PMA 2100 radiometer equipped with a PMA 2110 UVA detector with a $320-400 \mathrm{~nm}$ spectral range, placed accordingly over the $\mathrm{CPC}$. The accumulated radiation per unit of volume was determined using Eq. (8) [26]:

$E_{\mathrm{UV}, n}=E_{\mathrm{UV}, n-1}+\left(\Delta t_{n} \times \mathrm{UV}_{n} \times \frac{A_{\text {collector }}}{V_{\text {Total }}}\right)$

where $E_{\mathrm{UV}, n}$ is the accumulated radiation per unit of volume at interval $n\left(\mathrm{~kJ} \mathrm{~L}^{-1}\right) ; E_{\mathrm{UV}, n-1}$ is the accumulated radiation per unit of volume at interval $n-1\left(\mathrm{~kJ} \mathrm{~L}^{-1}\right) ; \Delta t_{n}$ is the elapsed time at interval $n(\mathrm{~s}) ; \mathrm{UV}_{n}$ is the incident radiation $\left(\mathrm{kW} \mathrm{m}^{-2}\right) ; A_{\text {collector }}$ is the reactor area of exposure $\left(\mathrm{m}^{2}\right) ; V_{\text {Total }}$ is the total treated volume $(\mathrm{L})$.

\subsection{Experimental design}

In order to evaluate the effect of operative conditions during the photo-degradation of indigo dye a three-level factorial design $\left(3^{2}\right)$ was carried out (Table 1 ). In Table 1 , the notations $(-1)$ and $(+1)$ represent the low and high levels, respectively, while (0) represents the middle level. The factorial design and ANOVA statistical tests were carried out with Statgraphics Centurion XVI (StatPoint Technologies, Inc.). In this work, the maximization of the TOC removal was selected as the optimization goal of the oxidative process whereas indigo $\left(\mathrm{mg} \mathrm{L}^{-1}\right)$ and peroxide $\left(\mathrm{mg} \mathrm{L}^{-1}\right)$ concentrations were selected as independent variables.

\section{Table 1}

Experimental conditions of the studied cases in $\mathrm{mg} \mathrm{L}^{-1}$.

\begin{tabular}{lcc}
\hline Coded variable & & \\
\hline Run & $\begin{array}{l}\text { Indigo: } x_{1}(\text { natural } \\
\left.\text { value } \mathrm{mg} \mathrm{L}^{-1}\right)\end{array}$ & $\begin{array}{l}\text { Peroxide: } x_{2} \text { (natural } \\
\text { value } \mathrm{mg} \mathrm{L}^{-1} \text { ) }\end{array}$ \\
\hline 1 & $-1(6.67)$ & $-1(257)$ \\
2 & $0(16.67)$ & $-1(257)$ \\
3 & $0(16.67)$ & $1(1280)$ \\
4 & $0(16.67)$ & $0(640)$ \\
5 & $1(33.33)$ & $1(1280)$ \\
6 & $-1(6.67)$ & $1(1280)$ \\
7 & $0(16.67)$ & $-1(257)$ \\
8 & $1(33.33)$ & $0(640)$ \\
9 & $-1(6.67)$ & $0(640)$ \\
10 & $1(33.33)$ & w
\end{tabular}

Note: For all experiments, iron and oxalate concentrations were kept constant. $\mathrm{Fe}^{2+}=1.87 \mathrm{mg} \mathrm{L}^{-1}$ and $\left[\mathrm{C}_{2} \mathrm{O}_{4}^{2-}\right]=65.67 \mathrm{mg} \mathrm{L}^{-1}$.
In all cases $2 \mathrm{~mL}$ aliquots was withdrawn over regular intervals of time for TOC and COD analyses. In photo-assisted experiments, a volume of $10 \mathrm{~mL}$ of the indigo solution was injected to each photochemical reactor, then a solution of ferrous oxalate $\left(\mathrm{C}_{2} \mathrm{O}_{4}{ }^{2-} / \mathrm{Fe}^{2+}=35\right)$ was added. By choosing such an oxalate-to-iron ratio, an excess of oxalate was assured which greatly extends the $\mathrm{pH}$ range for the Fenton reaction due to a strong complexation with iron $[28,29]$.

\subsection{Analytical methods}

The $\mathrm{H}_{2} \mathrm{O}_{2}$ concentration was determined using the ammonium metavanadate $\left(\mathrm{NH}_{4} \mathrm{VO}_{3}\right)$ method in a UV-visible Thermo Spectronic Genesys 20 spectrophotometer (USA) [30]. The mineralization degree of the indigo dye was evaluated through the Total Organic Carbon (TOC) concentration of each sample. For these measurements, the $\mathrm{pH}$ of each sample tube was gauged to 12 with $\mathrm{NaOH}(0.5 \mathrm{M})$ and reduced again with $\mathrm{Na}_{2} \mathrm{~S}_{2} \mathrm{O}_{4}\left(100 \mathrm{mg} \mathrm{L}^{-1}\right)$, to ensure that all the remaining indigo has been resolubilized. Measurements were performed using a Shimadzu TOC-V CPH analyzer (Japan). COD measurements were carried out according to standard methods in COD HACH digestion vials [31]. For HPLC, COD, toxicity and biodegradability analyses, the samples were treated with a $\mathrm{Na}_{2} \mathrm{~S}_{2} \mathrm{O}_{3}$ solution $\left(4 \mathrm{~g} \mathrm{~L}^{-1}\right)$ in order to remove residual peroxide and to prevent further oxidation [32].

The nitrate concentration of the samples was monitored by ion chromatography using a Dionex ICS-5000 DC chromatograph, a pre-packed IonPac AS11-HC column, an IonPac AG11-HC precolumn and a self-regenerating suppressor ASRS 300 . The mobile phase was sodium hydroxide $30 \mathrm{mM}$ and the flow rate was fixed at $1.5 \mathrm{~mL} \mathrm{~min}^{-1}$. The operation temperature was $35^{\circ} \mathrm{C}$. This analysis was only performed to the $16.67 \mathrm{mg} \mathrm{L}^{-1}$ of initial indigo concentration tests to assess the middle-concentration level.

Identification of reaction intermediates was performed through HPLC with a pre-packed HPLC Merck Polyspher OA-HY column (length, $300 \mathrm{~mm}$; inner diameter, $6.5 \mathrm{~mm}$ ), using an HP 1090 liquid chromatograph (USA) equipped with an HP 1047A refraction index detector. The column operated at $135 \mathrm{bar}$ and $30^{\circ} \mathrm{C}$ and the samples were injected manually using $20 \mu \mathrm{L}$ each time. The mobile phase consisted of $0.01 \mathrm{~N}$ sulfuric acid and the flow rate was fixed at $0.8 \mathrm{~mL} \mathrm{~min}^{-1}$ for all the identified compounds. For these determinations, the samples were filtered previously using $0.22-\mu \mathrm{m}$ Millipore cellulose membranes. This analysis was performed too only for the $16.67 \mathrm{mg} \mathrm{L}^{-1}$ indigo concentration tests.

\subsection{Biodegradability assays}

The Biological Oxygen Demand ( $\mathrm{BOD}_{5}$ ) determination was carried out with a manometric type sensor (VELP Scientifica ${ }^{\circledR}$ ), and the biodegradability of the photo-treated effluent was determined from the $\mathrm{BOD}_{5} / \mathrm{COD}$ ratio as indicated by the 

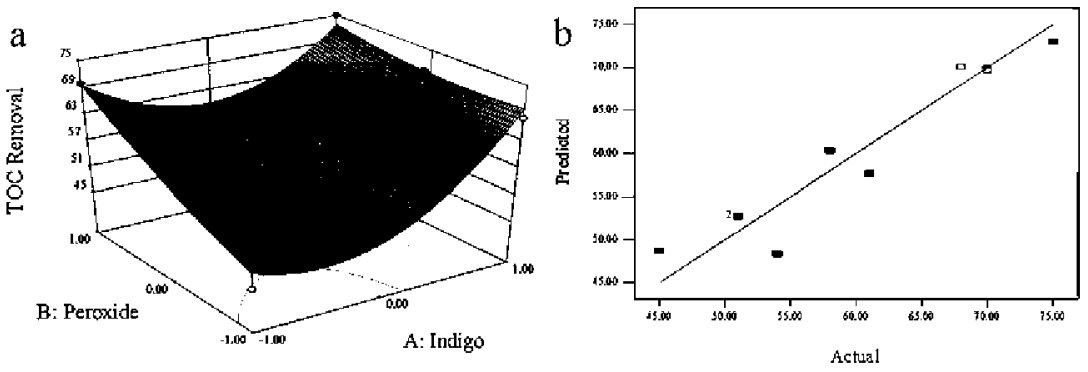

Fig. 2. (a) Response surface plot of the effect of $\mathrm{H}_{2} \mathrm{O}_{2}$ and indigo concentrations on TOC removal efficiency. (b) Predicted vs. Actual values plot. Reaction time $=180$ min, $\mathrm{Fe}^{2+}=1.87 \mathrm{mg} \mathrm{L}^{-1}, \mathrm{C}_{2} \mathrm{O}_{4}^{2-} / \mathrm{Fe}^{2+}=35$.

OECD 301 Test [33-36]. The volume of the solutions poured into the bottles was determined according to the theoretical oxygen demand without nitrification $\left(\operatorname{ThOD}_{\mathrm{NH}_{3}}\right)$. The formula is: $\mathrm{ThOD}_{\mathrm{NH}_{3}}=[16(2 c+((h-c l-3 n) / 2)+3 s+(5 p / 2)+$ $n a /(2-o))] / M$, with $\mathrm{C}_{c} \mathrm{H}_{h} \mathrm{Cl}_{C l} \mathrm{~N}_{n} \mathrm{Na}_{n a} \mathrm{O}_{o} \mathrm{P}_{p} \mathrm{~S}_{s}$ as the formula of the test compound and $M$ as its molecular weight [37]. The average concentration of the biomass was $160 \mathrm{mg}$ of suspended solids per liter of mineral nutrient medium. The inocula used for the test were activated sludge samples coming from the wastewater treatment facility at the Universidad Iberoamericana.

\subsection{Toxicity assays}

The assessment of toxicity was conducted to determine the median lethal concentration ( $\mathrm{LC}_{50}$ ) using the brine shrimp (Artemia salina). The use of brine shrimp as test organism is popular due to the ease of culture, short generation time and the commercial availability of its dormant eggs. Test variability is also greatly reduced because test organisms hatching from cysts have similar age, genotype and physiological conditions. Besides, A. salina has proven to perform well enough for aqueous media that have been treated by active oxygen species [35]. Furthermore, $\mathrm{LC}_{50}$ values obtained from $A$. salina seem to correlate well with $L_{50}$ estimates for mice (Mus musculus) $[38,39]$. The bioassay was carried out according to the technique described in Svensson et al. [40] and applied in Vedrenne et al. [41] for the undiluted photo-treated samples ([ Indigo $]_{0}=33.3 \mathrm{mg} \mathrm{L}^{-1},\left[\mathrm{H}_{2} \mathrm{O}_{2}\right]_{0}=1280 \mathrm{mg} \mathrm{L}^{-1}$ ) at four irradiation times $\left(E_{\mathrm{UV}}=0,60,90,180 \mathrm{~kJ} \mathrm{~L}^{-1}\right)$.

\section{Results and discussion}

This part of the investigation was oriented to evaluate the reduction efficiencies of the TOC concentration according to a series of known factors that affect the performance of the photoFenton process mediated with ferrous oxalate such as the (1) hydrogen peroxide (2) ferrous ion and (3) oxalate doses, (4) the initial concentration of indigo and (5) $\mathrm{pH}$. The concentrations of ferrous ion and oxalate were kept constant, namely $\mathrm{Fe}^{2+}=1.87 \mathrm{mg} \mathrm{L}^{-1}, \mathrm{C}_{2} \mathrm{O}_{4}^{2-} / \mathrm{Fe}^{2+}=35$. These values have proven to be adequate enough for wastewater treatment according to previous studies $[19,37]$. It did not seem reasonable to quantify the effect of $\mathrm{pH}$ on the efficiency of the treatment since it is already known that the Fenton's reaction enhanced with ferrous oxalate develops optimally at $\mathrm{pH}$ 5-6 [19]. Therefore, the only parameters that were examined against the TOC reduction efficiencies were the hydrogen peroxide dose and the initial concentration of indigo (see Table 1).

The statistical analysis carried out in Statgraphics (StatPoint Technologies, Inc.) allowed to obtain a semi-empirical quadratic model in terms of coded variables $\left(x_{1} \text { : [Indigo }\right]_{0}$ and $\left.x_{2}:\left[\mathrm{H}_{2} \mathrm{O}_{2}\right]_{0}\right)$ to represent the TOC removal of the indigo dye (Eq. (9)) after $180 \mathrm{~min}\left(80 \mathrm{~kJ} \mathrm{~L}^{-1}\right.$ of accumulated energy) of photo-treatment (see additionally Fig. 2a).

$$
\begin{aligned}
\text { TOC\% } & 52.7+6.16 \times x_{1}+6 \times x_{2}+11.7 \times x_{1}{ }^{2} \\
& -4.5 \times x_{1} \times x_{2}+1.57 \times x_{2}{ }^{2}
\end{aligned}
$$

The correlation coefficient $\left(r^{2}\right)\left(r_{\text {TOC }}^{2}=0.92\right)$ indicates that the fitted model explains $92 \%$ the variability in TOC removal. Also, the adjusted correlation coefficient $\left(r_{\text {Adj }}^{2}\right)$ indicated $\left(r_{\text {Adj TOC }}^{2}=0.81\right)$ that the quadratic model (Eq. (9)) is able to describe the performance of the photo-assisted process in the selected experimental range. The last fact can be evidenced by means Fig. $2 \mathrm{~b}$ where the predicted and actual values were plotted.

As mentioned in Section 2.3 (experimental design), the selection of the best operative conditions (indigo and peroxide concentrations) for the TOC removal of indigo was carried out in the optimization module of Statgraphics ${ }^{\circledR}$. As shown in Fig. 2a, the best operative condition (TOC removal: $73 \%$ ) was achieved when $33.33 \mathrm{mg} \mathrm{L}^{-1}$ of indigo and $1280 \mathrm{mg} \mathrm{L}^{-1}$ of peroxide were used. However, it is noteworthy that above $69 \%$ of TOC removal was also accomplished by using 257 and $640 \mathrm{mg} \mathrm{L}^{-1}$ of peroxide (Fig. 2a). In the sections to come, a further insight into the appropriateness of these conditions will be undertaken, emphasizing the question of whether deriving the effluent to a biological treatment technique or not.

\subsection{Effect of $\mathrm{H}_{2} \mathrm{O}_{2}$ and initial indigo concentration on TOC removal}

Fig. 2a presents the response surface plot for TOC removal as a function of the initial indigo and $\mathrm{H}_{2} \mathrm{O}_{2}$ concentrations. The reduction efficiencies for TOC range between $50 \%$ and $70 \%$, being the highest when the indigo and $\mathrm{H}_{2} \mathrm{O}_{2}$ concentrations were kept at its maximum $(+1)$. However, as the indigo concentration increases (from -1 to $+1, \mathrm{H}_{2} \mathrm{O}_{2}:-1$ ) similar results (TOC\% ${ }_{\text {Removal }} \sim 69 \%$ ) were also observed.

An increase of the indigo concentration implies higher concentrations of organic matter that can reduce the impact of adverse reactions (Eqs. (10)-(12)) since dye degradation has the highest reaction rate constant (Eq. (13)). Therefore, an excess of dye can hinder the reaction between $\mathrm{HO}^{*}$ and the reagents: $\mathrm{H}_{2} \mathrm{O}_{2}$ (Eq. (10)) and $\mathrm{Fe}^{2+}$ (Eq. (11)) which may have been the major route of $\mathrm{HO}^{*}$ consumption.

$$
\begin{aligned}
& \mathrm{HO}^{\bullet}+\mathrm{H}_{2} \mathrm{O}_{2} \rightarrow \mathrm{HO}_{2}^{\bullet}+\mathrm{H}_{2} \mathrm{O} \quad k=1.7-4.5 \times 10^{7} \mathrm{M}^{-1} \mathrm{~s}^{-1} \\
& \mathrm{HO}^{\bullet}+\mathrm{Fe}^{2+} \rightarrow \mathrm{Fe}^{3+}+\mathrm{OH}^{-} \quad k=2.6-5.8 \times 10^{8} \mathrm{M}^{-1} \mathrm{~s}^{-1} \\
& 2 \mathrm{HO}^{\bullet} \rightarrow \mathrm{H}_{2} \mathrm{O}_{2} \quad k=5-8 \times 10^{9} \mathrm{M}^{-1} \mathrm{~s}^{-1} \\
& \mathrm{HO}+\text { dye } \rightarrow \mathrm{H}_{2} \mathrm{O}+\text { dye } \quad k=10^{9}-10^{10} \mathrm{M}^{-1} \mathrm{~s}^{-1}
\end{aligned}
$$

It is well known that high peroxide-to-dye ratios drive undesirable reactions (Eqs. (10)-(12)) that consume $\mathrm{HO}^{\bullet}$ radicals $\left(E^{0}=2.8 \mathrm{~V}\right)$ and produce less powerful oxidant like $\mathrm{HO}_{2} \cdot\left(E^{0}=1.6 \mathrm{~V}\right)$. Also, 

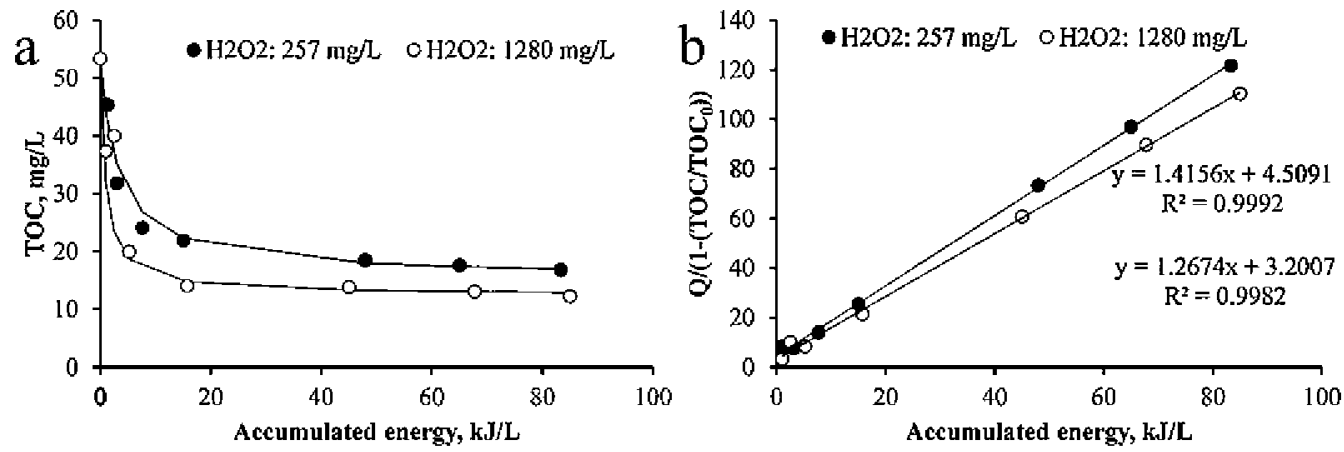

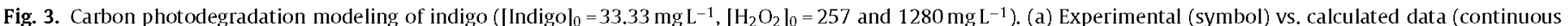
line), (b) Determination of the model constants ( $a$ and $b$ ).

hydroxyl radicals can decompose oxalate species into $\mathrm{CO}_{2}{ }^{--}$ $\left(E^{0}=1.9 \mathrm{~V}\right)$, reducing the oxidative capacity of the ferrous-oxalate process over time (see Eqs. (14) and (15)) [42-44].

$\mathrm{C}_{2} \mathrm{O}_{4}{ }^{2-}+\mathrm{HO} \cdot \rightarrow \mathrm{CO}_{2}+\mathrm{CO}_{2}^{\bullet-}+\mathrm{OH}^{-} \quad k=7.7 \times 10^{6} \mathrm{M}^{-1} \mathrm{~s}^{-1}$

$\mathrm{HC}_{2} \mathrm{O}_{4}{ }^{-}+\mathrm{HO}^{*} \rightarrow \mathrm{CO}_{2}+\mathrm{CO}_{2}{ }^{--}+\mathrm{H}_{2} \mathrm{O} \quad k=4.7 \times 10^{7} \mathrm{M}^{-1} \mathrm{~s}^{-1}(15)$

The fact of working with low peroxide concentrations $(-1)$ and high indigo concentrations $(+1)$ resulted in TOC removal percentages comparable to those obtained by using high peroxide $(+1)$ and indigo ( +1$)$ concentrations. Therefore, factors such as biodegradability and toxicity will be considered in order to select the best operative conditions for the pre-treatment stage (Section 3.3) $[45,46]$.

\subsection{Kinetic study}

In this section the best operative conditions $\left.\left(\left[\mathrm{H}_{2} \mathrm{O}_{2}\right]_{0}=1280 \mathrm{mg} \mathrm{L}^{-1} \text { and [Indigo }\right]_{0}=33.33 \mathrm{mg} \mathrm{L}^{-1}\right)$ determined through the experimental design were used to model the behavior of the TOC removal (Fig. 3a). In general, the decolorization or mineralization of dyes assisted by photo-Fenton processes can be satisfactorily described as first or second order reaction kinetics [47]. However, the kinetic of ferrous-oxalate complexes is thought to be quite complex because the photolytic destruction of oxalate complexes accelerates the catalyst regeneration and produces additional oxidative species, which can contribute to enhance the depletion of organic matter. Therefore, four kinetic models (zero-order, first-order, second-order and two-stage) were used to test the fitting of experimental data points obtained during the treatment of the simulated effluent. According to Table 2, zero, first and second-order models were inappropriate for modeling the mineralization of indigo whereas the two-stage model provides a good description of the kinetics of the mineralization of indigo.

As shown in Fig. 3a, the indigo mineralization occurs in two stages. The fast initial mineralization may be caused by a sharp generation of $\mathrm{HO}^{*}$ radicals from the reaction of iron and peroxide
(Eq. (4)) as well as by the photo-catalytic regeneration of iron (Eqs. (2) and (3)). The second stage is characterized by an appreciably reduction of the mineralization rate [48]. In this stage, both the low amounts of oxidant and oxalate became limiting factors in the photo-assisted process.

In the proposed two-stage model (Eq. (16)), TOC $_{0}$ and TOC $_{t}$ are the total organic carbon concentrations of the dye at the beginning of the treatment and after a given accumulation of energy, $E_{\mathrm{UV}}\left[Q=\mathrm{kJ} \mathrm{L}{ }^{-1}\right]$, respectively. In Eq. (16), $a$ and $b$ are two constants related to the decay rate and the remaining organic carbon in solution in a photo-assisted process which can be calculated through the linearization of Eq. (16) (see Eq. (17)) as mentioned by Chu et al. [48]. The values of $a$ and $b$ under different conditions can be obtained from the intercepts and slopes of the curves, respectively (Fig. 3b).

$\frac{\mathrm{TOC}_{t}}{\mathrm{TOC}_{0}}=1-\frac{Q}{a+b Q}$

$\frac{Q}{1-\mathrm{TOC} / \mathrm{TOC}_{0}}=a+b Q$

According to Chu et al. [48], the dye mineralization can be modeled by both, $a$ (the initial rate) and $b$ (the maximum oxidation capacity). At the beginning of the process Eq. (16) can be represented as Eq. (18) whose physical meaning is the removal rate of TOC during the photo-treatment of the dye. In this sense, higher $1 / a$ values produce faster carbon removal rates (Table 2 and Fig. 3a).

$\frac{d\left(C / C_{0}\right)}{d t}=-\frac{1}{a}$

Furthermore, when irradiation time is approaching infinity, the reciprocal constant $b$ (Eq. (19)) represents the maximum oxidation capacity of the oxidative process.

$\frac{1}{b}=1-\frac{C_{t} \rightarrow \infty}{C_{0}}$

As can be deduced by examining the $1 / b$ parameter, an increase in the peroxide concentration (from 257 to $1280 \mathrm{mg} \mathrm{L}^{-1}$ ) allowed

Table 2

Rate constants calculated for the kinetic models.

\begin{tabular}{|c|c|c|c|c|}
\hline \multirow[t]{4}{*}{ Model order } & \multicolumn{4}{|l|}{$r^{2}$} \\
\hline & \multicolumn{4}{|l|}{$\left[\mathrm{H}_{2} \mathrm{O}_{2}\right]_{0}$} \\
\hline & \multirow[t]{2}{*}{$257 \mathrm{mg} \mathrm{L}^{-1}$} & \multirow[t]{2}{*}{$1280 \mathrm{mg} \mathrm{L}^{-1}$} & \multicolumn{2}{|l|}{$k$-value } \\
\hline & & & $257 \mathrm{mg} \mathrm{L}^{-1}$ & $1280 \mathrm{mg} \mathrm{L}^{-1}$ \\
\hline Zero & 0.556 & 0.327 & -0.323 & -0.351 \\
\hline First & 0.680 & 0.414 & 0.011 & 0.013 \\
\hline Second & 0.797 & 0.938 & $4 \times 10^{-4}$ & $1.2 \times 10^{-3}$ \\
\hline Two-stage & 0.999 & 0.998 & $a^{-1}=0.221 b^{-1}=0.706$ & $a^{-1}=0.312 b^{-1}=0.789$ \\
\hline
\end{tabular}

Note: Indigo concentration: $33.33 \mathrm{mg} \mathrm{L}^{-1}$. 


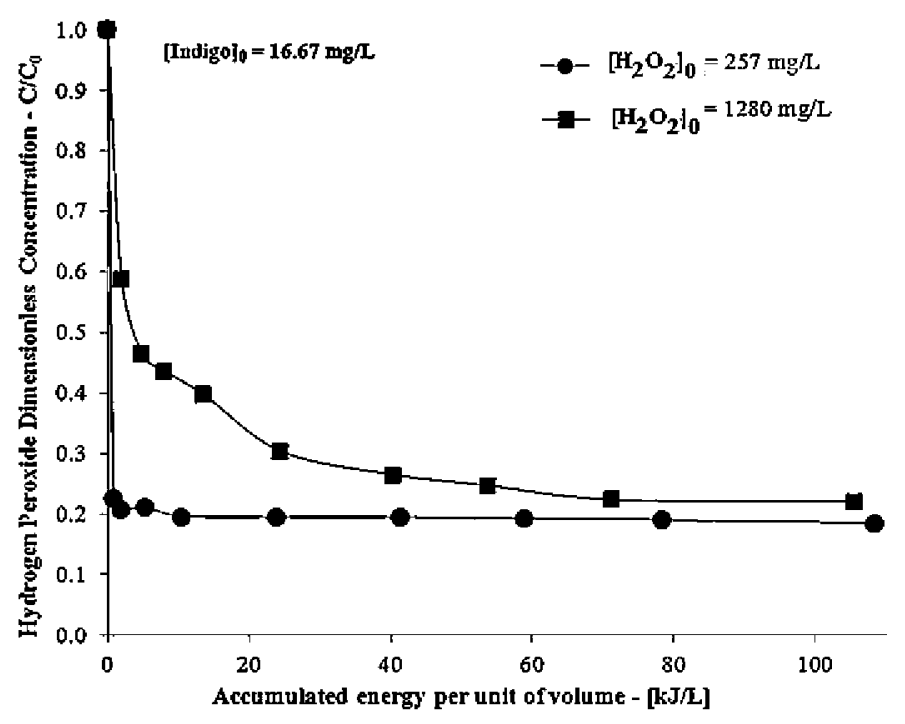

Fig. 4. Evolution of the $\mathrm{H}_{2} \mathrm{O}_{2}$ normalized concentration for $\left[\mathrm{H}_{2} \mathrm{O}_{2}\right]_{0}=257$ and $1280 \mathrm{mg} \mathrm{L}^{-1}$. Reaction time $=180 \mathrm{~min}, \mathrm{Fe}^{2+}=1.87 \mathrm{mg} \mathrm{L}^{-1}, \mathrm{C}_{2} \mathrm{O}_{4}{ }^{2-} / \mathrm{Fe}^{2+}=35$.

an slightly improvement of the percentage of mineralization (from $71 \%$ to $79 \%$ ). The last fact can be associated with the presence of undesirable reactions which decompose oxalate species and $\mathrm{HO}^{*}$ radicals into $\mathrm{CO}_{2}{ }^{-}$and $\mathrm{HO}_{2}{ }^{\bullet}$, respectively (Eqs. (10), (14) and (15)). From the data reported in Table 2 for $1 / b$, it was possible to calculate the residual TOC expected for the peroxide concentrations of 257 and $1280 \mathrm{mg} \mathrm{L}^{-1}$ (16.83 $\mathrm{mg}_{\mathrm{TOC}} \mathrm{L}^{-1}$ and $12.85 \mathrm{mg}_{\mathrm{TOC}} \mathrm{L}^{-1}$, respectively). As can be noted, the two-phase model provided a sound description of both the mineralization profile and the residual carbon achieved during the photo-assisted degradation of indigo.

In Fig. 4, it was observed that the $\mathrm{H}_{2} \mathrm{O}_{2}$ concentration decreased dramatically during the earlier stages of the reaction. The foregoing might suggest an important consumption of $\mathrm{H}_{2} \mathrm{O}_{2}$ as to produce hydroxyl radicals to degrade the dye and to trigger undesired reactions $[18,49]$. The residual peroxide concentration observed for the $\left[\mathrm{H}_{2} \mathrm{O}_{2}\right]_{0}=1280 \mathrm{mg} \mathrm{L}^{-1}$ curve is in average 5.2 times greater than that observed for the $\left[\mathrm{H}_{2} \mathrm{O}_{2}\right]_{0}=257 \mathrm{mg} \mathrm{L}^{-1}$ curve, both experiments for the $16.67 \mathrm{mg} \mathrm{L}^{-1}$ indigo concentration. This can be explained by the presence of organic matter (OM) which has an impact on the behavior of the $\mathrm{H}_{2} \mathrm{O}_{2}$ in two ways: (i) no further decomposition of $\mathrm{H}_{2} \mathrm{O}_{2}$ occurs just after its initial decrease, since the reaction of $\mathrm{OM}$ with $\mathrm{HO}^{*}$ overwhelms the reaction of $\mathrm{H}_{2} \mathrm{O}_{2}$ with $\mathrm{HO} *$, (ii)
Table 3

$\mathrm{BOD}_{5}$ and COD concentration values after $20 \mathrm{~kJ} \mathrm{~L}^{-1}$ of irradiation.

\begin{tabular}{rlrllr}
\hline [Indigo $]_{0}$ & \multicolumn{2}{l}{$\left[\mathrm{H}_{2} \mathrm{O}_{2}\right]_{0}=257 \mathrm{mg} \mathrm{L}$} & & \multicolumn{2}{c}{$\left[\mathrm{H}_{2} \mathrm{O}_{2}\right]_{0}=1280 \mathrm{mg} \mathrm{L}$} \\
\cline { 2 - 3 } & $\mathrm{BOD}_{5}$ & $\mathrm{COD}$ & & $\mathrm{BOD}_{5}$ & $\mathrm{COD}$ \\
\hline 6.66 & 370 & 617 & 392 & 395 \\
16.67 & 445 & 839 & & 432 & 720 \\
33.33 & 540 & 1421 & 590 & 1072 \\
\hline
\end{tabular}

Note: Concentration values reported in every case as mg L.

the presence of excess $\mathrm{OM}$ can hinder the reaction between $\mathrm{HO}^{*}$ and the ferrous ion, which may have been the major route of $\mathrm{HO}^{*}$ consumption in the absence of organic matter [44,50,51]. Additionally, unbalanced rates of $\mathrm{Fe}^{2+}$ to $\mathrm{H}_{2} \mathrm{O}_{2}$ might lead to early reaction stops caused by the degradation of oxalate, the precipitation of $\mathrm{Fe}(\mathrm{OH})_{3}$, or to efficiency decreases provoked by iron acting as a radical scavenger $[52,53]$.

\subsection{Study of the biodegradability and toxicity of the effluent}

The initial biodegradability of the untreated effluent $\left(\mathrm{BOD}_{5} / \mathrm{COD}=0.20\right)$ suggests that it cannot be treated by conventional biological processes. In every case, the pre-treatment proposed in this work improved the biodegradability of the effluent reaching a level in which a conventional wastewater biological process is possible. The $\mathrm{BOD}_{5}$ and $\mathrm{COD}$ concentration values at $20 \mathrm{~kJ} \mathrm{~L}^{-1}$ are reported in Table 3. In Fig. $5,20 \mathrm{~kJ} \mathrm{~L}^{-1}$ of irradiation are enough to increase the $\mathrm{BOD}_{5} / \mathrm{COD}$ ratio above 0.4 (biodegradability threshold) for every studied solution except for the $33.3 \mathrm{mg} \mathrm{L}^{-1}$ solution treated with low peroxide, which was barely below [54,55]. As a result, the biodegradability of the effluent is basically affected by the concentration of indigo and $\mathrm{H}_{2} \mathrm{O}_{2}$.

As the concentration of indigo increases from 6.67 to $33.3 \mathrm{mg} \mathrm{L}^{-1}$ $\left(\left[\mathrm{H}_{2} \mathrm{O}_{2}\right]_{0}=257 \mathrm{mg} \mathrm{L}^{-1}\right)$, the effluent's biodegradability is reduced up to a $63 \%$ due to the supplied peroxide was unable to produce enough $\mathrm{HO}^{*}$ radicals. As mentioned by Oller et al. [21], this condition leads to the formation of by-products that are potentially more recalcitrant than the parent compound.

In the same line, the HPLC analyses (Figs. 6 and 7) confirmed the presence of structures such as 1,4-benzoquinone, which are biorecalcitrant [56]. 1,4-benzoquinone is commonly reported as an intermediate compound produced when the degraded parental compound exhibits aromatic rings [22,57]. At further reaction stages, the presence of lactic, malic, glycolic, fumaric and acrylic

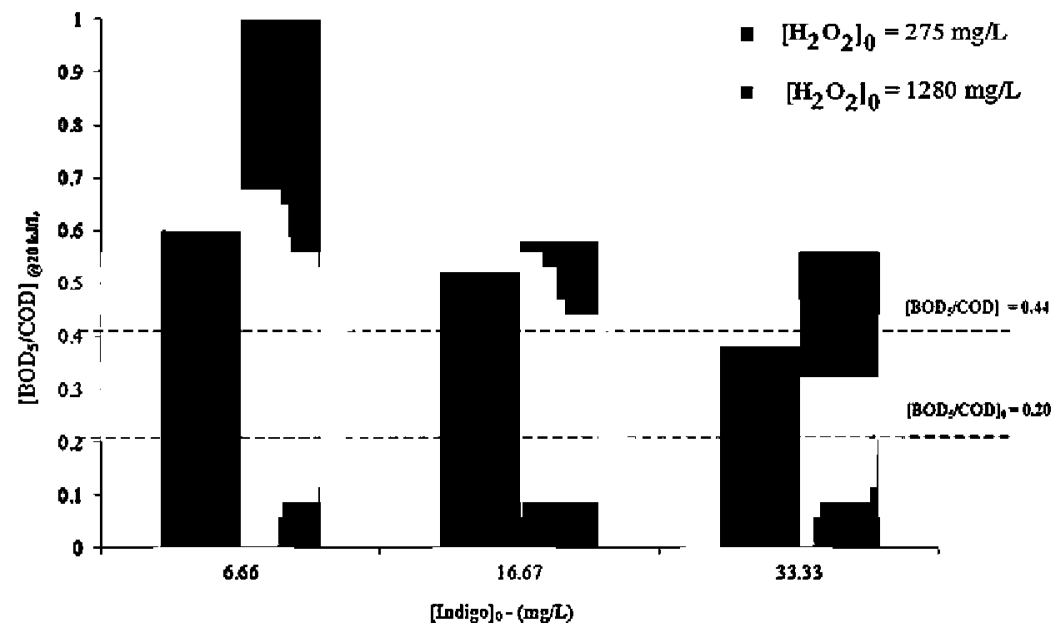

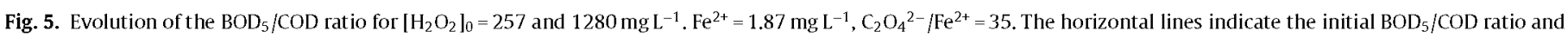
the biodegradability threshold. 


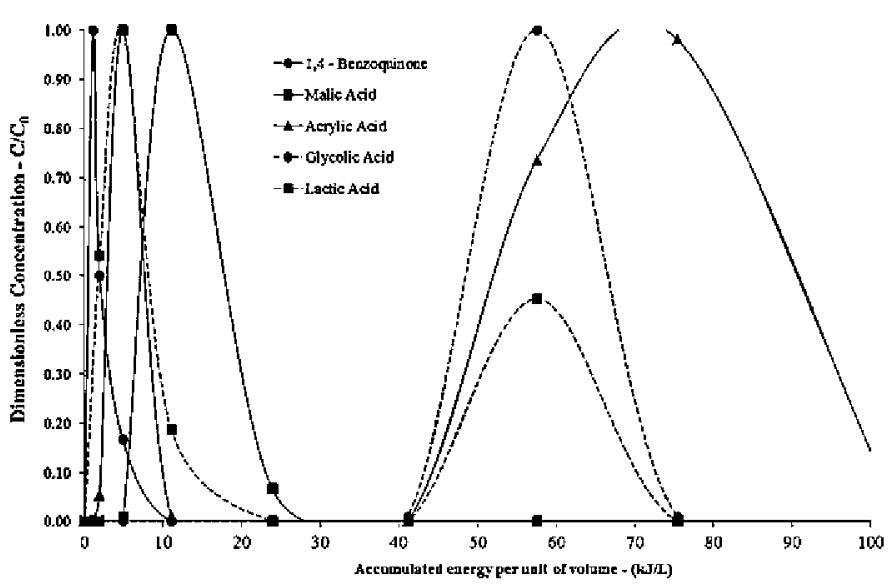

Fig. 6. Distribution of the reaction intermediate products for $\left[\mathrm{H}_{2} \mathrm{O}_{2}\right]_{0}=257 \mathrm{mg} \mathrm{L}^{-1}$, $\mathrm{Fe}^{2+}=1.87 \mathrm{mg} \mathrm{L}^{-1}, \mathrm{C}_{2} \mathrm{O}_{4}{ }^{2-} / \mathrm{Fe}^{2+}=35$.

acids were observed, which are typical degradation products that occur when aromatic rings are being destroyed by an electrophilic addition [22]. According to Arslan-Alaton et al. [58], the presence of the before mentioned carboxylic acids indicate that a sufficient carbon mineralization degree was achieved. For the two studied cases, the initial oxidant conditions determined the extent of this degradation as well as the amount and variety of the intermediate species.

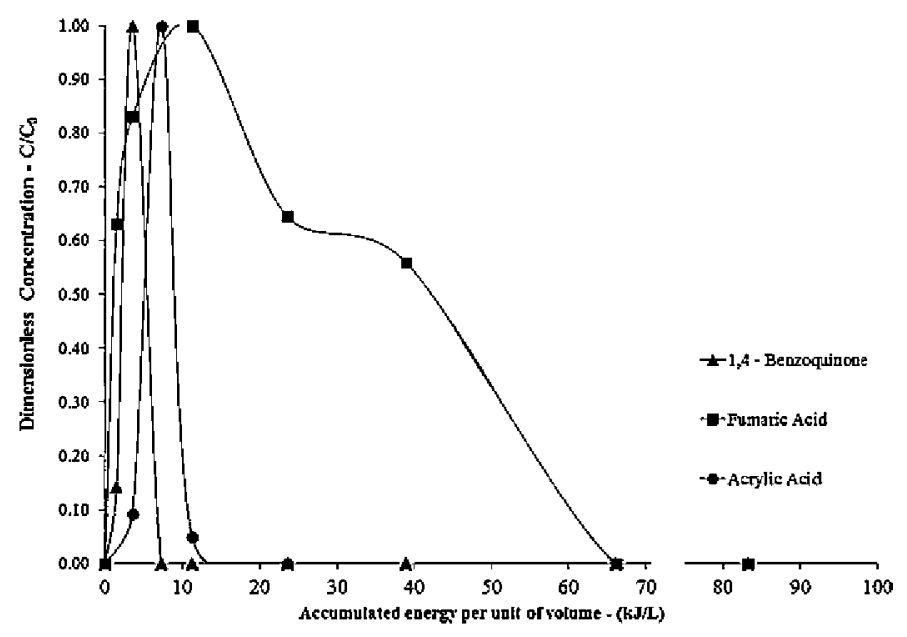

Fig. 7. Distribution of the reaction intermediate products for $\left[\mathrm{H}_{2} \mathrm{O}_{2}\right]_{0}=1280 \mathrm{mg} \mathrm{L}^{-1}$, $\mathrm{Fe}^{2+}=1.87 \mathrm{mg} \mathrm{L}^{-1}, \mathrm{C}_{2} \mathrm{O}_{4}{ }^{2-} / \mathrm{Fe}^{2+}=35$.

At low peroxide concentrations (Figs. 6 and $8 ; 257 \mathrm{mg} \mathrm{L}^{-1}$ ), the principal degradation products found were lactic, malic, glycolic and acrylic acids. On the other hand, high peroxide concentrations (Figs. 7 and $8 ; 1280 \mathrm{mg} \mathrm{L}^{-1}$ ) conduced to a much faster oxidation of indigo to short-chain organic acids. In this case, the complex aromatic structures such as 1,4-benzoquinone disappeared in the first minutes of the reaction (less than $5 \mathrm{~kJ} \mathrm{~L}^{-1}$ ), originating simpler structures such as acrylic and fumaric acids after 180 min of

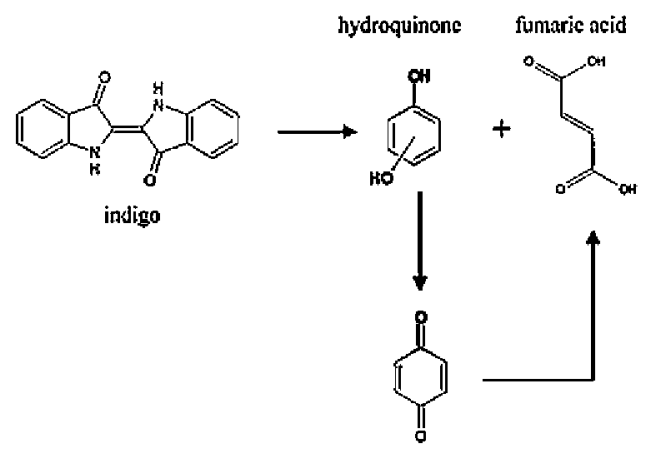

1,4 benzoquinone
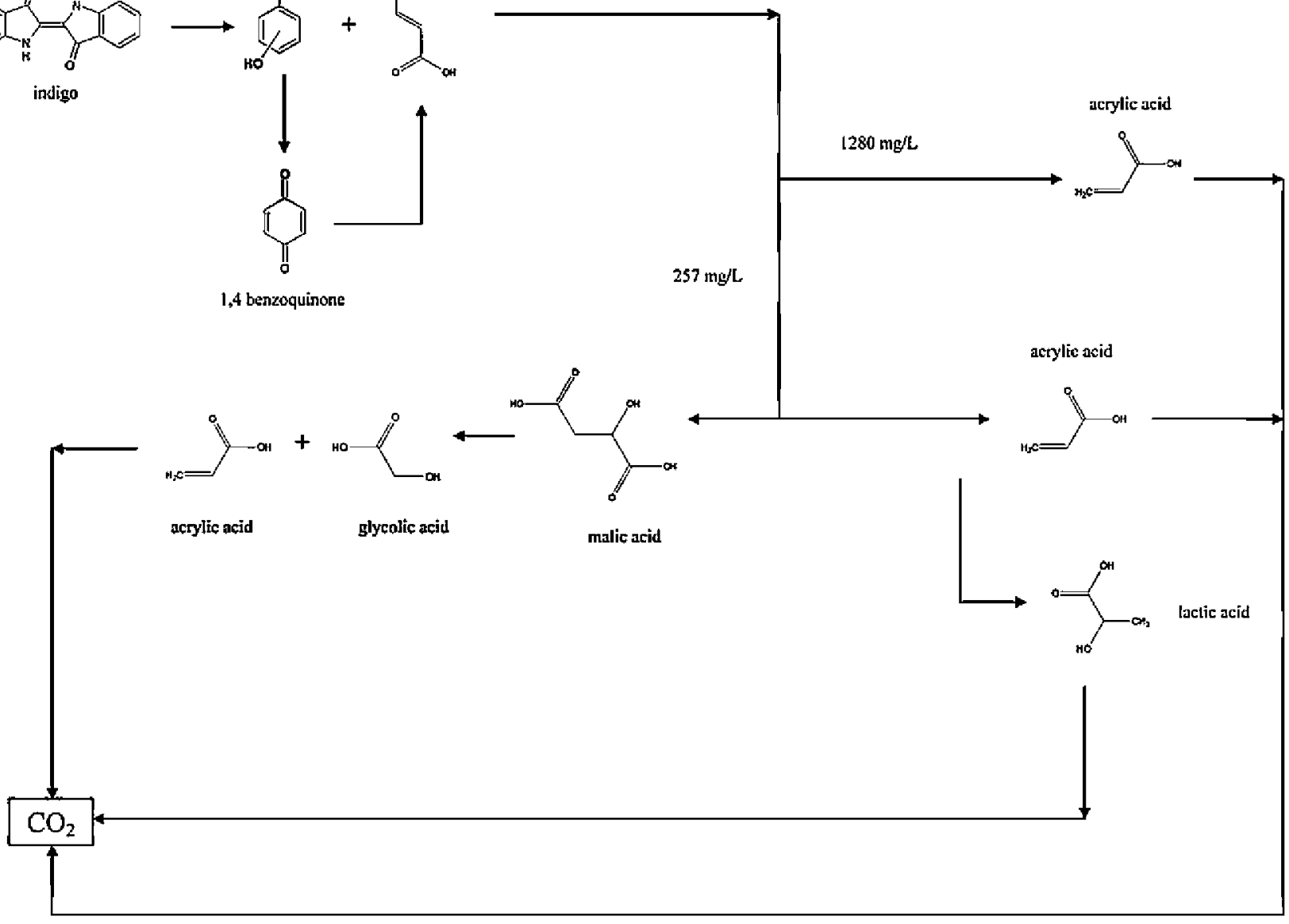

Fig. 8. General indigo degradation pathway for $\left[\mathrm{H}_{2} \mathrm{O}_{2}\right]_{0}=257$ and $1280 \mathrm{mg} \mathrm{L}^{-1}$. Reaction time $=180 \mathrm{~min}^{2} \mathrm{Fe}^{2+}=1.87 \mathrm{mg} \mathrm{L}^{-1}, \mathrm{C}_{2} \mathrm{O}_{4}{ }^{2-} / \mathrm{Fe}^{2+}=35$. 


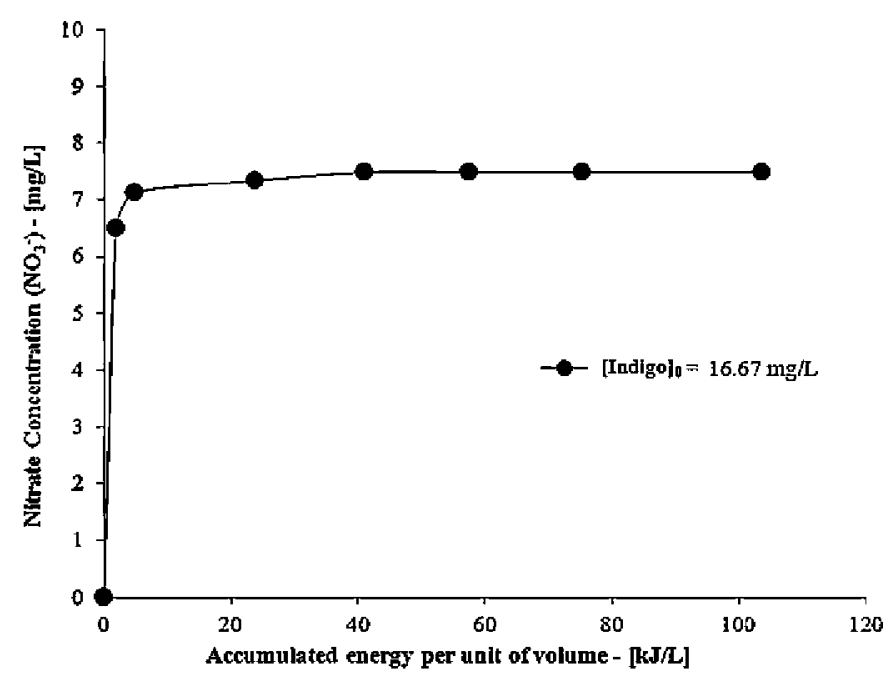

Fig. 9. Evolution of the nitrate concentration for [Indigo $]_{0}=16.67 \mathrm{mg} \mathrm{L}^{-1}$ and $\left[\mathrm{H}_{2} \mathrm{O}_{2}\right]_{0}=257 \mathrm{mg} \mathrm{L}^{-1}$. Reaction time $=180 \mathrm{~min}, \mathrm{Fe}^{2+}=1.87 \mathrm{mg} \mathrm{L}^{-1}, \mathrm{C}_{2} \mathrm{O}_{4}{ }^{2-} / \mathrm{Fe}^{2+}=35$.

treatment $\left(80 \mathrm{~kJ} \mathrm{~L}^{-1}\right)$. This short-chain carboxylic acids tend to be persistent in the effluent and are the origin of the slow TOC decay even when hydroxyl radicals are available [59]. The observed degradation pathway is qualitatively represented in Fig. 8 for the two tested peroxide concentrations.

For both studied cases $\left(\mathrm{H}_{2} \mathrm{O}_{2}=257\right.$ and $\left.1280 \mathrm{mg} \mathrm{L}^{-1}\right)$, nitrate was found at stoichiometric concentration, which indicates a degradation of the dye molecule. The presence of nitrate in the photo-treated effluent indicated that the dye molecule had been efficiently oxidized, since nitrogen-containing compounds forms $\mathrm{NO}_{3}{ }^{-}$[60-62]. It was observed that nitrate concentration increased immediately after the first reaction instants, which means that nitrogen is being liberated directly from the indigo molecule (Figs. 8 and 9). At $80 \mathrm{~kJ} \mathrm{~L}^{-1}(180 \mathrm{~min})$, the experimental nitrate concentrations were 6.75 and $5.70 \mathrm{mg} \mathrm{L}^{-1}$ when $\left[\mathrm{H}_{2} \mathrm{O}_{2}\right]_{0}=257$ and $1280 \mathrm{mg} \mathrm{L}^{-1}$, respectively, each showing a deviation percentage of $4.91 \%$ and $22.75 \%$ from the theoretical nitrate concentration, calculated with the initial concentration values and the removal percentages.

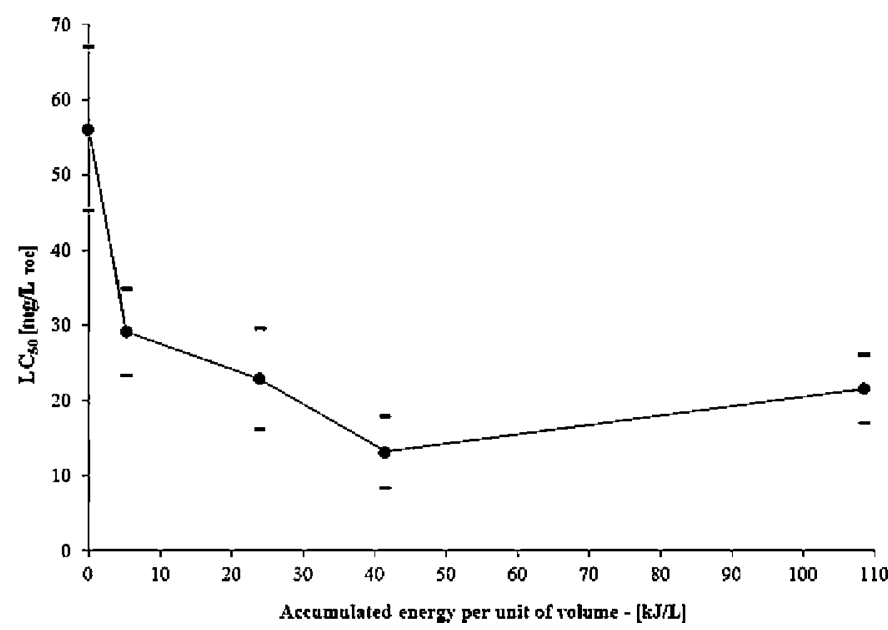

Fig. 10. Evolution of the $\mathrm{LC}_{50}$ for Artemia salina. [Indigo $]_{0}=33.3 \mathrm{mg} \mathrm{L}^{-1}$ and $\left[\mathrm{H}_{2} \mathrm{O}_{2}\right]_{0}=1280 \mathrm{mg} \mathrm{L}^{-1}$. Reaction time $=180 \mathrm{~min}, \mathrm{Fe}^{2+}=1.87 \mathrm{mg} \mathrm{L}^{-1}, \mathrm{C}_{2} \mathrm{O}_{4}{ }^{2-} / \mathrm{Fe}^{2+}=35$
The median lethal concentration $\left(\mathrm{LC}_{50}\right)$ for $A$. salina is reported in TOC concentration units because it has been demonstrated that a negative relationship between toxicity and dissolved organic carbon concentrations (TOC) exists [38,63]. The assessment of toxicity has been carried out on the samples treated under the highest concentrations of dye and peroxide ([Indigo $]_{0}=33.3 \mathrm{mg} \mathrm{L}^{-1}$, $\left.\left[\mathrm{H}_{2} \mathrm{O}_{2}\right]_{0}=1280 \mathrm{mg} \mathrm{L}^{-1}\right)$. The evaluation of the toxicity at different stages of the photo-Fenton treatment, as shown in Fig. 10, reveals an overall descent in $\mathrm{LC}_{50}$ values. A global $61.5 \%$ reduction in the $\mathrm{LC}_{50}$ was achieved after $110 \mathrm{~kJ} \mathrm{~L}^{-1}$ yet the highest $\mathrm{LC}_{50}$ reduction was obtained after $40 \mathrm{~kJ} \mathrm{~L}^{-1}(76.5 \%)$. This latter fact highlights the importance of carrying out an assessment of toxicity at different reaction stages as to examine the response of organisms to intermediate products, which may be more or less toxic than parent compounds [64]. Moreover, if toxicity information is crossed with biodegradability tests, the extent of the phototreatment might be reasonably fixed to a point in which the effluent no longer poses any hazards for its further biological treatment or discharge [65].

Finally, it is paramount to highlight that the degradation of indigo is likely to be successfully accomplished by using low oxidant concentrations $\left(\mathrm{H}_{2} \mathrm{O}_{2}=257 \mathrm{mg} \mathrm{L}^{-1}\right)$ in the selected concentration range (6.67-33.33 $\mathrm{mg} \mathrm{L}^{-1}$ ). By carrying out this treatment, a biodegradable effluent will be generated, reducing the consumption of $\mathrm{H}_{2} \mathrm{O}_{2}$ up to an $80 \%$. On the other hand, low ferrous ion concentrations ( $1.87 \mathrm{mg} \mathrm{L}^{-1}$ ) avoid the need of any further separation once the chemical pre-treatment of indigo has been carried out. Moreover, the operation at near-neutral conditions $(\mathrm{pH} 6)$ presents two positive aspects regarding the chemical pretreatment of indigo under the described process. The reduction of the consumption of reagents during the conditioning process of the effluent and the minimization of undesirable precipitates caused during dramatic $\mathrm{pH}$ changes.

\section{Conclusions}

Based on the present study on the treatment of a series of indigo-dyed simulated wastewaters by the solar photo-assisted Fenton process mediated with ferrous oxalates, the following conclusions can be drawn. The best treatment conditions found for indigo are the ones that generally follow low $\mathrm{H}_{2} \mathrm{O}_{2}$ concentrations, at an initial $\mathrm{pH}$ of 5-6. These conditions produce noticeable reductions in pollutant concentration, keeping the iron concentration low and, thus, economizing the reagent. The use of oxalate ion as a ligand of iron improves the performance of small iron concentrations at near neutral $\mathrm{pH}$ without precipitation of iron species. An optimization approach revealed that for a correct organic carbon mineralization (TOC), low peroxide concentrations are more effective to minimize the consumption of the oxalate reagent produced by an excessive dose of $\mathrm{H}_{2} \mathrm{O}_{2}$. The observed biodegradability is increased due to the formation of compounds of less complex structures, namely carboxylic acids, which are more easily recognized and degraded by bacteria. Furthermore, the presence of nitrate in the treated effluent from the earliest reaction stages also hints on the increase in biodegradability of the effluent and the destruction of the dye. Toxicity bioassays confirmed the effectiveness of the photo-treatment aiming a further biological treatment.

In summary, it is suggested that the combined use of the photoFenton process with biological treatment could be a promising alternative to the existing decontamination methods; the basic aim of the photo-Fenton process would be the reduction of the recalcitrant character of indigo, while further biological treatment would be intended to treat the remaining organic matter and the compounds resulting from the photodegradation. 


\section{Acknowledgments}

We acknowledge financial assistance from Universidad Iberoamericana and CONACyT.

\section{References}

[1] Y. Anjaneyulu, N. Sreedhara, D. Suman-Raj, Decolourization of industrial effluents - available methods and emerging technologies - a review, Rev. Environ. Sci. Biotechnol. 4 (2005) 245-273.

[2] F. Hai, K. Yamamoto, K. Fukushi, Hybrid treatment systems for dye wastewater, Crit. Rev. Environ. Sci. Technol. 37 (2007) 315-377.

[3] F. vander Zee, S. Villaverde, Combined anaerobic-aerobic treat ment of azo dyes - a short review of bioreactor studies, Water Res. 39 (2005) 1425-1440.

[4] A.B. dos Santos, F.J. Cervantes, J. van Lier, Review paper on current technologies for decolourisation of textile wastewaters: perspectives for anaerobic biotechnology, Bioresour. Technol. 98 (2007) 2369-2385.

[5] E. Khelifi, H. Gannoun, Y. Touhami, H. Bouallagui, M. Hamdi, Aerobic decolourization of the indigo dye-containing textile wastewater using continuous combined bioreactors, J. Hazard. Mater. 152 (2008) 683-689.

[6] N. Tan, A. van Leeuwen, P. Slenders, H. Temmink, G. Lettinga, J. Field, Fate and biodegradability of sulfonated aromatic amines, Biodegradation 16 (2005) 527-537.

[7] P.A. Carneiro, G.A. Umbuzeiro, D.P. Oliveira, M.V. Zanoni, Assessment of water contamination caused by a mutagenic textile effluent/dyehouse effluent bearing disperse dyes, J. Hazard. Mater. 174 (2010) 694-699.

[8] U.R. Lakshmi, V.C. Srivastava, I.D. Mall, D.H. Lataye, Rice husk ash as an effective adsorbent: evaluation of adsorptive characteristics for Indigo Carmine dye, J. Environ. Manage. 90 (2009) 710-720.

[9] J. Trujillo, V. Sanchez, A. Colin, R.A. Morales, Removal of indigo blue in aqueous solution using $\mathrm{Fe} / \mathrm{Cu}$ nanoparticles and $\mathrm{C} / \mathrm{Fe}-\mathrm{Cu}$ nanoalloy composites, Water, Air, Soil Pollut. 207 (2010) 307-317.

[10] M. Unlu, H. Yukseler, U. Yetis, Indigo dyeing wastewater reclamation by membrane-based filtration and coagulation processes, Desalination 240 (2009) $178-185$.

[11] N. Uzal, L. Yilmaz, U. Yetis, Microfiltration: a pretreatment alternative for indigo dyeing textile wastewater, Desalination 199 (2006) 515-517.

[12] M.S. Secula, I. Cretescu, S. Petrescu, An experimental study of indigo carmine removal from aqueous solution by electrocoagulation, Desalination 277 (2011) $227-235$.

[13] A.G.S. Prado, J.D. Torres, E.A. Faria, S.C.L. Dias, Comparative adsorption studies of indigo carmine dye on chitin and chitosan, J. Colloid Interface Sci. 277 (2004) $43-47$.

[14] A.Y. Zahrim, C. Tizaoui, N. Hilal, Coagulation with polymers for nanofiltration pre-treatment of highly concentrated dyes: a review, Desalination 266 (2011) $1-16$.

[15] S. Malato-Rodríguez, P. Fernández, M. Maldonado, J. Blanco, W. Gernjak, Decontamination and disinfection of water by solar photocatalysis: recent overview and trends, Catal. Today 147 (2009) 1-59.

[16] E. Brillas, I. Sires, M. Oturan, Electro-Fenton process and related electrochemical technologies based on Fenton's reaction chemistry, Chem. Rev. 109 (2009) $6570-6631$.

[17] J. Pignatello, E. Oliveros, A. MacKay, Advanced oxidation process for organic contaminant destruction based on the Fenton reaction and related chemistry, Crit. Rev. Environ. Sci. Technol. 36 (2006) 1-84.

[18] C.Y. Kwan, W. Chu, A study of the reaction mechanisms of the degradation of 2,4-dichlorophenoxyacetic acid by oxalate-mediated photooxidation, Water Res. 38 (2004) 4213-4221.

[19] C.Y. Kwan, W. Chu, The role of organic ligands in ferrous-induced photochemical degradation of 2,4-dichlorophenoxyacetic acid, Chemosphere 67 (2007) 1601-1611.

[20] A. Zapata, I. Oller, C. Sirtori, A. Rodríguez, J. Sánchez, A. López, A. Mezcua, S. Malato, Decontamination of industrial wastewater containing pesticides by combining large-scale homogeneous solar photocatalysis and biological treatment, Chem. Eng. J. 160 (2010) 447-456.

[21] I. Oller, S. Malato, J.A. Sanchez, Combination of advanced oxidation processes and biological treatments for wastewater decontamination - a review, Sci. Total Environ. 409 (2011) 4141-4166.

[22] D. Hermosilla, M. Cortijo, C.P. Huang, The role of iron on the degradation and mineralization of organic compounds using conventional Fenton and photoFenton processes, Chem. Eng. J. 155 (2009) 637-646.

[23] M.A. Sanromán, M. Pazos, M.T. Ricart, C. Cameselle, Electrochemical decolourisation of structurally different dyes, Chemosphere 57 (2004) 233-239.

[24] H.Zollinger, Color Chemistry: Synthesis, Propert ies and Ap plicat ions of Organic Dyes and Pigments, 3rd ed., Wiley-VCH, Weinheim, Germany, 2003.

[25] W. Gernjak, T. Krutzler, A. Glaser. S. Malato, Photo-Fenton treatment of water containing natural phenolic pollutants, Chemosphere 50 (2003) 71-78.

[26] J. Blanco, S. Malato, Solar Detoxification, Plataforma Solar de Almería, United Nations Educational, Scientific and Cultural Organization, Spain, 2003.

[27] S. Malato-Rodríguez, J. Blanco Gálvez, M. Maldonado Rubio, P. Fernández Ibáñez, D. Alarcón Padilla, M. Collares Pereira, J. Farinha Mendes, J. Correia de Oliveira, Engineering of solar photocatalytic collectors, Sol. Energy 77 (2004) $513-524$
[28] J. Jeong, ]. Yoon, pH effect on $\mathrm{OH}$ radical production in photo/ferrioxalate sys tem, Water Res. 39 (2005) 2893-2900.

[29] C.T. Benatti, C.R.G. Tavares, T.A. Guedes, Optimization of Fenton's oxidation of chemical laboratory wastewaters using the response surface methodology, J. Environ. Manage. 80 (2006) 66-74.

[30] R.F. Pupo Nogueira, C.Oliveira, C. Parterlini, Simple and fast spectrophotometric determination of $\mathrm{H}_{2} \mathrm{O}_{2}$ in photo-Fenton reactions using metavanadate, Talanta 66 (2005) 86-91.

[31] APHA, Standard Methods for the Examination of Water and Wastewater, 20th ed., American Public Health Association, Washington, DC, 1999.

[32] I. Talinli, G.K. Anderson, Interference of hydrogen peroxide on the standard COD test, Water Res. 26 (1992) 107-110.

[33] OECD, Guidelines for the Testing of Chemicals, Section 3: Degradation and Accumulation, Ready Biodegradability Test, OECD, Paris, 1992.

[34] M.E. Lapertot, C. Pulgarin, Biodegradability assessment of several priority hazardous substances: choice, application and relevance regarding toxicity and bacterial activity, Chemosphere 65 (2006) 682-690.

[35] P. Reuschenbach, U. Pagga, U.Strotmann, A critical comparison of respirometric biodegradation tests based on OECD 301 and related test methods, Water Res. 37 (2003) 1571-1582.

[36] I. Oller, S. Malato, J.A Sanchez Combination of advanced oxidation processes and biological treatments for wastewater decontamination-a review, Sci. Total Environ. 409 (2011) 4141-4166.

[37] D. Prato-García, R. Vasquez-Medrano, M. Hernández-Esparza, Solar photoassisted advanced oxidation of synthet ic phenolic wastewaters using ferrioxalate complexes, Sol. Energy 83 (2009) 306-315.

[38] R.S. Matthews, Artemia salina as a test organism for measuring superoxide mediated toxicity, Free Radic. Biol. Med. 18 (5) (1995) 919-922.

[39] A. Lagarto-Parra, R. Silva-Yhebra, I. Guerra-Sardiñas, L. Iglesias-Buela, Comparative study of the assay of Artemia salina L. and the estimate of the medium lethal dose ( $L D_{50}$ value) in mice, to determine oral acute toxicity of plant extracts, Phytomedicine 8 (5) (2001) 395-400.

[40] B.M. Svensson, L. Mathiasson, M. Mårtensson, S. Bergström, Artemia salina as test organism for assessment of acute toxicity of leachate water from landfills, Environ. Monit. Assess. 102 (2005) 309-321.

[41] M. Vedrenne, R. Vasquez-Medrano, D. Prato-García, B.A. Fontana-Uribe, J.G. Ibanez, Characterization and detoxification of a mature landfill leachate using a combined coagulation-flocculation/photo Fenton treatment, J. Hazard. Mater. 205-206 (2012) 208-215.

[42] J. Jeong, J. Yoon, Dual roles of $\mathrm{CO}_{2}^{-}$for degrading synthetic photo/ferrioxalate system, Water Res. 38 (2004) 3532-3540.

[43] T. Oppenländer, Photochemical Purification of Water and Air. Advanced Oxidation Processes (AOPs): Principles, Reaction Mechanisms, Reactor Concepts, 1st ed., VCH-Wiley Verlag, Weinheim, Germany, 2003.

[44] D. Kassinos, N. Varnava, C. Michael, P. Piera, Homogeneous oxidation of aqueous solutions of atrazine and fenitrothion through dark and photo-Fenton reactions, Chemosphere 74 (2009) 866-872.

[45] I. Arslan-Alaton, G. Tureli, T. Olmez-Hanci, Treatment of azo dye production wastewaters using Photo-Fenton-like advanced oxidat ion processes: optimization by response surface methodology, J. Photochem. Photobiol. A 202 (2009) $142-153$.

[46] T. Maezono, M. Tokumura, M. Sekine, Y. Kawase, Hydroxyl radical concentration profile in photo-Fenton oxidation process: generation and consumption of hydroxyl radicals during the discoloration of azo-dye Orange II, Chemosphere $82(2011) 1422-1430$

[47] X. Dong, W. Ding, X. Zhang, X. Liang, Mechanism and kinetics model of degradation of synthetic dyes by $\mathrm{UV}$-vis/ $/ \mathrm{H}_{2} \mathrm{O}_{2} /$ Ferrioxalate complexes, Dyes Pigments 74 (2007) $470-476$.

[48] W. Chu, C.Y. Kwan, K.H. Chan, S.K. Kam, A study of kinetic modelling and reaction pathway of 2,4-dichlorophenol transformation by photo-Fenton-like oxidation, J. Hazard. Mater. B121 (2005) 119-126.

[49] J. Monteagudo, A Duran, I, San Martin, M. Aguirre, Effect of continuous addition of $\mathrm{H}_{2} \mathrm{O}_{2}$ and air injection on ferrioxalate-assisted solar photo-Fenton degradation of Orange II, Appl. Catal. B: Environ. 89 (2009) 510-518.

[50] E. Neyens, J. Baeyens, A review of classic Fenton's peroxidation as an advanced oxidation technique, J. Hazard. Mater. B 98 (2003) 33-50.

[51] V. Sakkas, C. Stalikas, T. Albanis, Review: photocatalytic degradation using design of experiments: a review and example of the Congo red degradation, J. Hazard. Mater. 175 (2010) 33-44.

[52] H. Ramirez, C.A. Costa, L.M. Madeira, Experimental design to optimize the degradation of the synthetic dye Orange II using Fenton's reagent, Catal. Today 107-108 (2005) 68-76.

[53] H. Zhang, H.J. Choi, P. Canazo, C.P. Huang Multivariate approach to the Fenton process for the treatment of landfill leachate, J. Hazard. Mater. 161 (2009) $1306-1312$.

[54] Z. Frontistis, N.P. Xekoukoulotakis, E. Hapeshi, D. Venieri, D. Fatta-Kassinos, D. Mantzavinos, Fast degradation of estrogen hormones in environmental matrices by photo-Fenton oxidation under simulated solar radiation, Chem. Eng. J 178 (2011) $175-182$.

[55] Metcalf \& Eddy, Wastewater Engineering: Treatment and Reuse, 4th ed, McGraw Hill, New York, 2003.

[56] A. Amat, A. Arques, A. Garcia, L. Santos, R. Vicente, I. Oller, M. Maldonado, S Malato, A reliable monitoring of the biocompatibility of an effluent along an oxidative treatment by sequential bioassays and chemical analyses, Water Res. 43 (2009) 784-792. 
[57] R. Torres, V.Sarria, P. Peringer C. Pulgarín, Elect rochemical treatment of industrial wastewater containing 5-amino-6-methyl-2-benzimidazolone: toward an electrochemical-biological coupling, Water Res. 37 (2003) 3118-3124.

[58] I. Arslan-Alaton, B.H. Gursoy, J.E. Schmidt, Advanced oxidation of acid and reactive dyes: effect of Fenton treatment on aerobic, anoxic and anaerobic processes, Dyes Pigments 78 (2008) 117-130.

[59] C. Flox, P.L. Cabot, F. Centellas, J.A. Garrido, R.M. Rodríguez, C. Arias, E. Brillas, Solar photoelectro-Fenton degradation of cresols using a flow reactor with a boron-doped diamond anode, Appl. Catal. B: Environ. 75 (2007) 17-28.

[60] C. Flox, S. Ammar, C. Arias, E. Brillas, A.V. Vargas-Zavala, R. Abdelhedi, ElectroFenton and photoelectron-Fenton degradation of indigo carmine in acidic aqueous medium, Appl. Catal. B: Environ. 67 (2006) 93-104.

[61] F. Lebreux, F. Buzzo, I. Marko, Studies in the oxidation of carboxylic acids: new twists for an old reaction. Synthesis of various cyclic systems and substituted orthoesters, ECS Trans. 13 (2008) 1-10, http://dx.doi.org/ $10.1149 / 1.3013282$.

[62] V. Kavitha, K. Palanivelu, The role of ferrous ion in Fenton and photo Fenton processes for the degradation of phenol, Chemosphere 55 (2004) $1235-1243$.

[63] A. Zapata, T. Velegraki, J.A. Sânchez-Pérez, D. Mantzavinos, M.I. Maldonado, S Malato, Solar photo-Fenton treatment of pesticides in water: effect of iron concentration on degradation and assessment of ecotoxicity and biodegradability, Appl. Catal. B: Environ. 88 (2009) 448-454.

[64] L. Rizzo, Bioassays as a tool for evaluating advanced oxidation processes in water and wastewater treatment, Water Res, 45 (2011) 4311-4340.

[65] D. Fatta-Kassinos, I.K. Kalavrouziotis, P.H. Koukoulakis, M.I. Vasquez, The risks associated with wastewater reuse and xenobiotics in the agroecological environment, Sci. Total Environ, 409 (2011) 3555-3563. 